Environmental Sciences Division

\title{
Bamboo: an overlooked biomass resource?
}

\author{
J. M. O. Scurlock \\ Environmental Sciences Division \\ Oak Ridge National Laboratory \\ P.O. Box 2008 \\ Oak Ridge, TN 37831-6407 \\ U.S.A. \\ D. C. Dayton and B. Hames \\ National Renewable Energy Laboratory \\ 1617 Cole Boulevard, MS 3311 \\ Golden, CO 80401 \\ U.S.A. \\ Environmental Sciences Division \\ Publication No. 4963 \\ Date Published: January 2000 \\ Prepared for the \\ U.S. DEPARTMENT OF ENERGY \\ Office of Transportation Technologies \\ EB 5203000 \\ and \\ Office of Utility Technologies \\ EB 2404000 \\ Prepared by the \\ OAK RIDGE NATIONAL LABORATORY \\ Oak Ridge, Tennessee 37831-6422 \\ managed by

\section{LOCKHEED MARTIN ENERGY RESEARCH CORP.} \\ for the \\ U.S. DEPARTMENT OF ENERGY \\ under contract DE-AC05-96OR22464
}





\section{Contents}

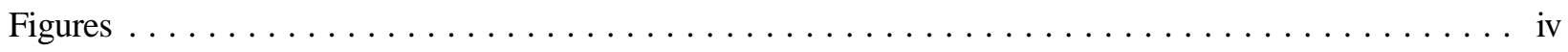

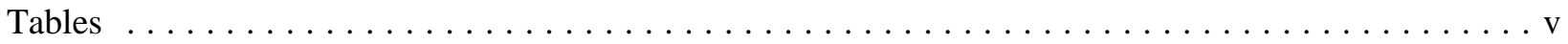

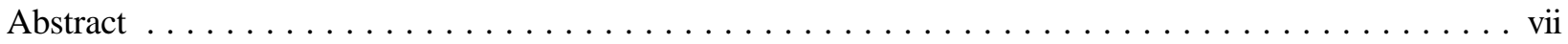

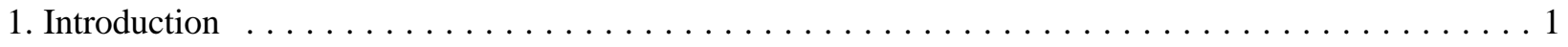

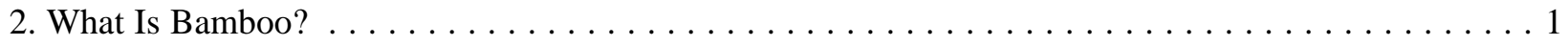

3. Commercial Applications of Various Bamboo Species $\ldots \ldots \ldots \ldots \ldots \ldots \ldots \ldots \ldots \ldots \ldots$

4. Physiological Characteristics $\ldots \ldots \ldots \ldots \ldots \ldots \ldots \ldots \ldots \ldots \ldots \ldots \ldots \ldots \ldots \ldots \ldots \ldots$

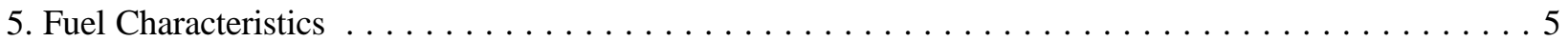

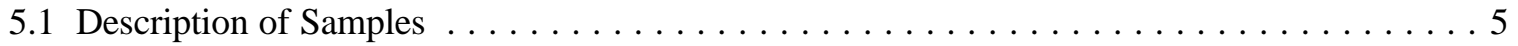

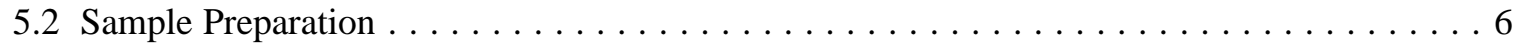

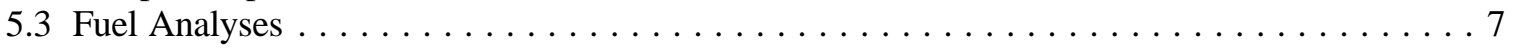

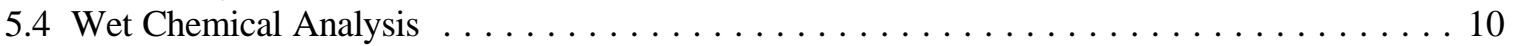

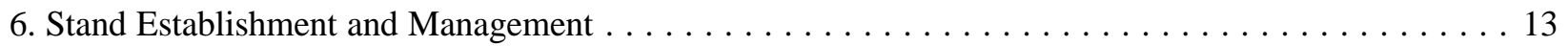

7. Productivity of Bamboo in Asia and South America $\ldots \ldots \ldots \ldots \ldots \ldots \ldots \ldots \ldots \ldots$

8. Limited Experience with Bamboo in the USA $\ldots \ldots \ldots \ldots \ldots \ldots \ldots \ldots \ldots \ldots \ldots \ldots \ldots \ldots \ldots \ldots$

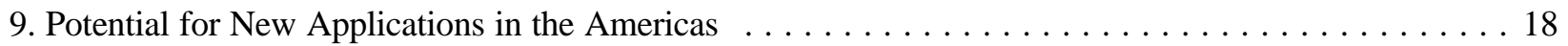

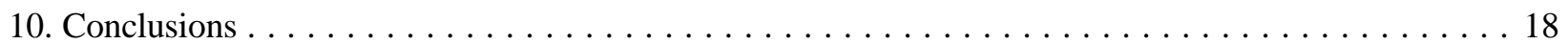

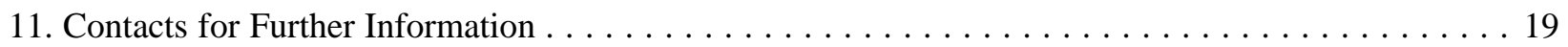

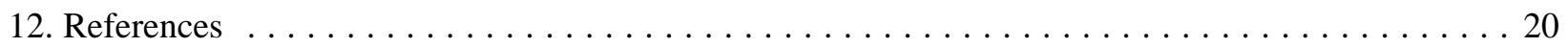

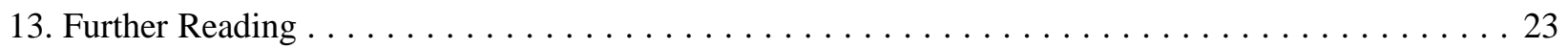




\section{Figures}

Figure 1. Experimental stand (clonal repository) of Phyllostachys bambusoides, cultivar White Crookstem, at the USDA-ARS/ University of Georgia Plant Genetic Resources Conservation Unit in Griffin, Georgia, USA. Culm diameter is about $5 \mathrm{~cm}$. Photograph taken August 1999 by G.R. Lovell,

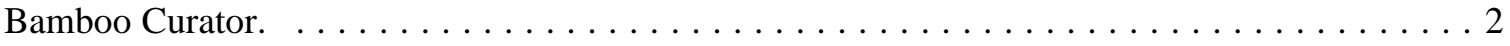

Figure 2. Stand (clonal repository) of Phyllostachys nigra, cultivar Henon, at the USDA-ARS/ University of Georgia Plant Genetic Resources Conservation Unit in Griffin, Georgia, USA. Maximum culm diameter is about $11 \mathrm{~cm}$, although this size has not been achieved in the stand pictured. Photograph taken August 1999 by G.R. Lovell, Bamboo Curator. . . . . . . . . . . . . . . . . . . . . . 6

Figure 3. Stand (clonal repository) of Phyllostachys bissetii at the USDA-ARS/ University of Georgia Plant Genetic Resources Conservation Unit in Griffin, Georgia, USA. Culm diameter is about $2.5 \mathrm{~cm}$. Photograph taken August 1999 by G.R. Lovell, Bamboo Curator. . . . . . . . . . . . . . . 7 


\section{Tables}

Page

Table 1 . Fuel analyses for selected bamboo samples $\ldots \ldots \ldots \ldots \ldots \ldots \ldots \ldots \ldots \ldots \ldots$

Table 2. Comparison of selected fuel properties of bamboo with other bioenergy crops $\ldots \ldots \ldots \ldots 10$

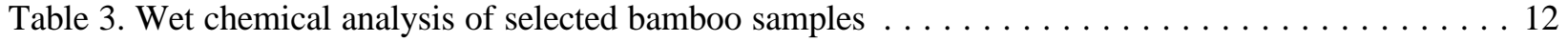

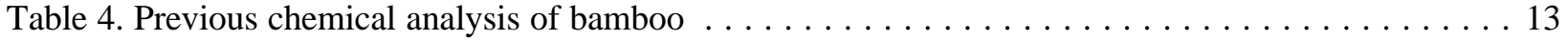

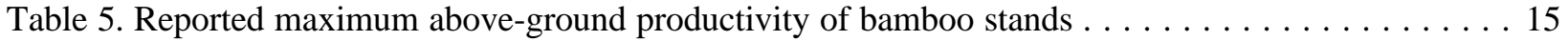





\begin{abstract}
Scurlock, J. M. O., D. C. Dayton and B. Hames (2000) Bamboo: an overlooked biomass resource? ORNL/TM-1999/264. Oak Ridge National Laboratory, Oak Ridge, Tennessee. 34 pp.

Bamboo is the common term applied to a broad group (1250 species) of large woody grasses, ranging from $10 \mathrm{~cm}$ to $40 \mathrm{~m}$ in height. Already in everyday use by about 2.5 billion people, mostly for fiber and food within Asia, bamboo may have potential as a bioenergy or fiber crop for niche markets, although some reports of its high productivity seem to be exaggerated. Literature on bamboo productivity is scarce, with most reports coming from various parts of Asia. There is little evidence overall that bamboo is significantly more productive than many other candidate bioenergy crops, but it shares a number of desirable fuel characteristics with certain other bioenergy feedstocks, such as low ash content and alkali index. Its heating value is lower than many woody biomass feedstocks but higher than most agricultural residues, grasses and straws. Although non-fuel applications of bamboo biomass may be actually more profitable than energy recovery, there may also be potential for co-production of bioenergy together with other bamboo processing. A significant drawback is the difficulty of selective breeding, given the lack of knowledge of flowering physiology. Further research is also required on propagation techniques, establishment and stand management, and mechanized harvesting needs to be developed.
\end{abstract}





\section{Introduction}

It may be observed cynically that every 5-10 years a new "magic feedstock" appears on the bioenergy scene, a new Philosopher's Stone about which great claims are made concerning its productivity, its ease of integration into existing markets for growing and fuel supply, its life-cycle analysis, and so on. Some of these novel candidate feedstocks may not be so new - they may have been considered and dismissed 20 years ago, or they may be already in widespread use outside the industrialized world. Bamboo is such a candidate, carrying with it a degree of Eastern mysticism: yet remarkably little is known about this entire sub-family of tall graminaceous plants, despite its everyday utilization, mostly for fiber and food, by about 2.5 billion people - over $40 \%$ of the world's population.

This review evaluates bamboo as a potential bioenergy feedstock, and tackles some of the myths and facts surrounding it - its "prodigious" productivity, its "disastrous" flowering, its multiple uses, etc. A limited range of bamboo species are characterized with respect to fuel quality, and a number of research recommendations are concluded.

\section{What Is Bamboo?}

Bamboo is the vernacular or common term for members of a particular taxonomic group of large woody grasses (subfamily Bambusoideae, family Andropogoneae/Poaceae). Bamboos encompass 1250 species within 75 genera, most of which are relatively fast-growing, attaining stand maturity within five years, but flowering infrequently. Dwarf bamboos may be as little as $10 \mathrm{~cm}$ in height, but stands of tall species may attain 15-20 m, and the largest known (e.g. Dendrocalamus giganteus) grow up to $40 \mathrm{~m}$ in height and 30 $\mathrm{cm}$ in culm (stem) diameter. Bamboos are distributed mostly in the tropics, but occur naturally in subtropical and temperate zones of all continents except Europe, at latitudes from $46^{\circ} \mathrm{N}$ to $47^{\circ} \mathrm{S}$ and from sea level to $4000 \mathrm{~m}$ elevation (IFAR/INBAR, 1991, Tewari, 1992). Asia accounts for about 1000 species, covering an area of over 180,000 $\mathrm{km}^{2}$ (the size of Missouri, half the size of Germany, or about $2 \%$ of U.S. total land area). Most of this comprises natural stands of native species rather than plantations or introductions. China alone has about 300 species in 44 genera, occupying $33,000 \mathrm{~km}^{2}$ or $3 \%$ of the country's total forest area (Qiu et al., 1992). Another major bamboo-producing country is India, with 130 species covering $96,000 \mathrm{~km}^{2}$ or about 13\% of the total forested area (Shanmughavel and Francis, 1996). Other nations with significant bamboo production and utilization include Bangladesh, Indonesia and Thailand.

The taxonomy of bamboos is still poorly understood, at least in part because of the infrequent flowering of many species (at intervals of 30-60 years). Major economic species include the following:

Dendrocalamus strictus - native to India. Solid culms, of greatest economic importance in India, where only about 10 out of more than 100 bamboo species are commercially exploited. Used mostly for papermaking and construction.

Dendrocalamus asper - thought to be native to Thailand. Thailand intends to propagate plantlets of this species since much of the present edible bamboo shoot production is from natural forests and not sustainable (IFAR/INBAR, 1991).

Thyrsostachys siamensis - native to Thailand. Used for construction in both rural and urban areas of Thailand; also cultivated for edible shoots.

Phyllostachys pubescens - sometimes described as Phyllostachys edulis. Originally from China, where it occurs extensively $\left(20,000 \mathrm{~km}^{2}\right.$ or $60 \%$ of total bamboo cover); introduced to Japan about 1750 . The 
largest of the Phyllostachys genus, this species is harvested for both poles and edible shoots throughout South-East Asia. This species requires a climate with precipitation of 1200-1800 mm, mean annual temperature of $13-20^{\circ} \mathrm{C}$ and monthly mean minimum temperatures no lower than freezing (Qiu et al., 1992).

Phyllostachys bambusoides - native to China, but extensively cultivated in Japan since 1866. The largest and most commercially valuable of this genus after Phyllostachys pubescens, producing good-quality wood. Hardier and more cold-tolerant than the latter (Chao, 1989). See Figure 1.

Bamboo has been neglected or ignored in the past by tropical foresters, who tend to concentrate on timber trees at the expense of traditional multi-purpose woody species such as bamboo and rattan (IFAR/INBAR, 1991). Literature on the dynamics and productivity of natural bamboo stands is meagre, and reports from plantation stands are almost non-existent (Shanmughavel and Francis, 1996). Bamboo has been used for handicrafts and building material in India and China for thousands of years, yet its potential contribution to

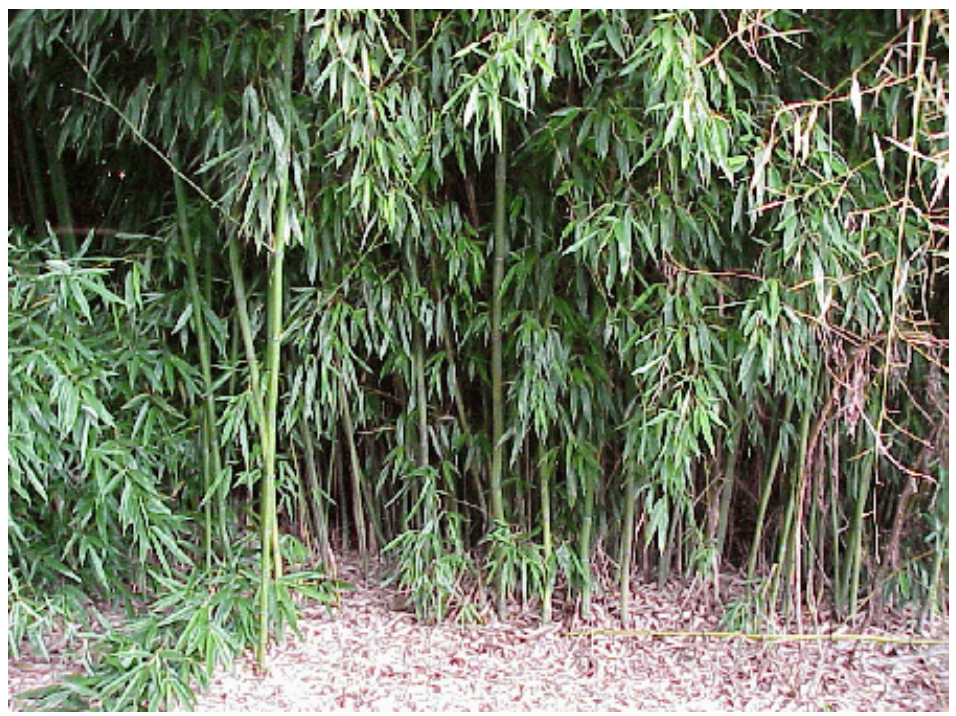

Figure 1. Experimental stand (clonal repository) of Phyllostachys bambusoides, cultivar White Crookstem, at the USDA-ARS/ University of Georgia Plant Genetic Resources Conservation Unit in Griffin, Georgia, USA. Culm diameter is about $5 \mathrm{~cm}$. Photograph taken August 1999 by G.R. Lovell, Bamboo Curator.

sustainable natural resource management has only recently been recognized. Unfortunately, most bamboo is harvested from forest stands at a rate which exceeds natural growth, so current utilization is anything but sustainable (IFAR/INBAR, 1991; Tewari, 1992).

\section{Commercial Applications of Various Bamboo Species}

Many Asian species of bamboo have strong, light and flexible woody stems, which lend themselves to applications as a construction material - one of the most notable modern uses being temporary scaffolding poles which are often seen surrounding the most modern of high-rise buildings in Asian countries. Bamboo 
utilization in South America is modest by comparison, except in certain local areas where indigenous species have been used for centuries, and where some Asian bamboos have been introduced (notably an international project for bamboo housing in Costa Rica). African use of bamboo is more limited and recent, since there are few native species except in Madagascar, although indigenous and introduced bamboo has been used in Kenya for soil stabilization, construction and fuel (IFAR/INBAR, 1991) and in Tanzania for water pipes (Lipangile, 1987). Worldwide commercial bamboo utilization is reported to be 20 million tonnes per annum. It is unclear whether this figure represents dry weight or (more likely) harvested weight at about $15 \%$ moisture content - but this number is considered unreliable since about $80 \%$ of bamboo is used locally and statistics are hard to obtain. More than half of this amount is harvested and utilized by poor people in rural areas. Total revenues from bamboo and its products were estimated in the 1980s at $\$ 4.5$ billion (IFAR/INBAR, 1991).

Approximately 1500 commercial applications of bamboo have been identified - mostly in Asia, except where noted below. They may be divided up into the following broad categories:

Construction and reinforcing fibers - these include agricultural and fishing tools, handicrafts, musical instruments, furniture, civil engineering (bridges, scaffolding poles), domestic building (house frames, walls, window frames, roofs, interior dividers).

Paper, textiles and board - (including rayon, plywood, oriented strand board, laminated flooring). Bamboo fibers are relatively long (1.5-3.2 mm) and thus ideal for paper production (El Bassam, 1998). Paper production in China dates back 2000 years, whilst in India, 2.2 million tonnes of bamboo per year are processed into pulp, making up about two-thirds of total pulp production (Adamson et al., 1978;

IFAR/INBAR, 1991). At least eight North American suppliers are importing and marketing tongue-andgroove flooring made from laminated bamboo, which is said to be as hard, durable and dimensionally stable as oak or other hardwood flooring (e.g. Plyboo America Inc., Kirkville, NY). Bamboo culms are sliced into strips, which are boiled to remove starch, dried, and laminated into solid boards using urea-formaldehyde adhesives. The boards may be treated with preservatives such as boric acid, before or after laminating, or both, and a darker amber color may be produced by pressure-steaming the bamboo to carbonize it. Although the adhesive tends to emit formaldehyde for a long time after production, the amount of ureaformaldehyde resin in a laminated product is much less than in a panel board product (Environmental Building News, 1999).

Food - bamboo shoots of a number of species are a well-known feature of Chinese and other Asian cuisine, generally imported into the USA in canned form (one estimate suggests 30,000 t/year in the early 1990s). Exports from Taiwan are worth $\$ 50$ million annually, and those from Thailand $\$ 30$ million, with much of this going to meet Japanese demand.

Combustion and other bioenergy applications - a preliminary literature search found no references to the use of bamboo as an energy feedstock, although anecdotal descriptions of bamboo as a fuel are commonplace. Molini and Irizarry (1983) proposed the use of bamboo as a fuel for power generation in Puerto Rico in preference to sugar cane, since its lower moisture content at harvest obviates the need for drying, but they provide few data in support of their case. Limited experience has been gained using de-lignified bamboo pulp as a substrate for ethanolic fermentation (Ram and Seenayya, 1991). Early work on preparing a diesel-like fuel from bamboo culms (Piatti, 1947) is cited by Tewari (1992); the process appears to have been the pyrolysis of "black liquor" from bamboo pulping, but does not seem to have progressed beyond the laboratory scale (Piatti, 1947). 


\section{Physiological Characteristics}

Bamboos vary across a wide range of physiological characteristics, so the following information is merely illustrative, and mostly concerns the tall bamboos of likely interest as biomass resources. In general, bamboos can be classified as sympodial (clumped) or monopodial (spreading): tropical bamboos are sympodial, whereas temperate species can be of either category (El Bassam, 1998). Although some bamboos can adapt to varying environments, most require relatively warm and humid conditions (e.g. mean annual temperature of at least $15-20^{\circ} \mathrm{C}$ and annual precipitation of at least $1000-1500 \mathrm{~mm}$ ).

Shoot buds appear as swellings on the side of the underground rhizomes, which generally occupy the top $30-50 \mathrm{~cm}$ of soil and may spread for tens of metres. With the onset of warm spring weather, the bud lengthens and develops into a compact upright shoot which forms a sharp point and penetrates the ground surface. After emergence there is little radial growth of the shoot, with "growth" taking the form of massive elongation of internodes, as much as $0.5 \mathrm{~m} /$ week in the case of tall bamboos, until the shoot is the approximately the same height as the rest of the stand. At this point, sheaths are shed and leafy branches emerge from the internodes near the top of the shoot. Further growth over the next few years comprises thickening of the walls of the stem and increases in wood density (Sturkie et al., 1968). Compared with other tall flowering plants, this pattern of growth may give a misleading impression of high productivity - in fact, all that may be observed is an (albeit rapid) re-distribution of previously stored reserves.

The reported leaf area index of mature stands is generally high, e.g. 8.02 for P. pubescens (Qiu et al., 1992) and 11.6 for $P$. bambusoides (Isagi et al., 1993). Such a dense canopy may absorb up to $95 \%$ of incident solar radiation (Qiu et al., 1992).

The reported pattern of leaf fall for most bamboos is semi-deciduous, with leaves shed at the end of the growing season (e.g. Bambusa sp. growing at Auburn, Alabama; Sturkie et al., 1968) or during the following growing season. $P$. pubescens renews its leaves on a 2 -year cycle, with most leaf fall taking place in the spring, beginning with the second growing season after shoot emergence. This biennial pattern of leaf renewal may be reflected in a biennial pattern of shoot emergence, with alternating "good" and "poor" years of new shoot production (Qiu et al., 1992).

The pattern of flowering in bamboos varies with species. A few (e.g. Bambusa atra, native to the Andaman Islands of the eastern Indian Ocean) are known to flower frequently, even annually. Others, such as Bambusa vulgaris, flower a few culms at a time. However, the majority - for example, Dendrocalamus strictus - display gregarious flowering, whereby an entire clump at one location produces flowers and then dies back over the course of 2-3 years. This happens typically every 30-40 years (more than 60 years in some cases), and is therefore observed quite rarely, so the physiology of flowering is still little understood. Clear-cutting does not appear to halt stand mortality, although some species can be induced to develop new shoots for a year or two before finally dying altogether. As a consequence of the rarity of flowering, the taxonomy of bamboos is still confused and based largely on vegetative features such as leaf anatomy, arrangement of vascular bundles in leaf sheaths and culms, etc. (Tewari, 1992).

A few genera, e.g. Phyllostachys and Arundinaria, have been reported to recover after flowering (Tewari, 1992). For example, P. bambusoides collected from China in 1926 and grown at Byron, Georgia, USA, began to flower in 1989, but recovered with vigorous vegetative growth by 1993 (G.R. Lovell, pers. comm.). The threat of catastrophic flowering need not pose an economic problem for bamboo growers, as long as uneven-aged propagation material is maintained, and entire stands are replaced before they approach flowering age. 
Unlike other highly-productive members of the Andropogoneae/Poaceae family (e.g. sugar cane, switchgrass, miscanthus), the entire bamboo sub-family (Bambusoideae) lacks the $\mathrm{C}_{4}$ photosynthetic pathway and anatomy (Jones, 1985). In the absence of this feature (which may lead to higher water-use and nutrient-use efficiencies under high light conditions), the maximum possible productivity of bamboos such as $P$. pubescens is unlikely to greatly exceed that of other bioenergy crops with $\mathrm{C}_{3}$ photosynthesis such as short-rotation willow coppice.

\section{Fuel Characteristics}

\subsection{Description of Samples}

Nine bamboo samples were obtained from G.R. Lovell, Bamboo Curator for the U.S. Department of Agriculture Agricultural Research Service (USDA-ARS) at the University of Georgia Plant Genetic Resources Conservation Unit in Griffin, Georgia. Three different ages of three different bamboo species were sampled for analysis to determine the fuel characteristics of the bamboo samples in relation to other biomass feedstocks with potential for electricity and fuel production, and to determine how the fuel properties change as the plant grows under carefully controlled conditions. What follows is a description of each of the bamboos analyzed. All bamboo stands were established on Norfolk Loamy fine sand soils with slight slope $\left(<5^{\circ}\right)$, following their transfer from Savannah, Georgia, around 1978.

Phyllostachys nigra, cultivar Henon (Figure 2): These rhizomes originated in Nagasaki, Japan and were obtained in 1909 from a Japanese bamboo grower by W.D. Hills, an agricultural explorer. This monopodial bamboo grows to a maximum height of $20 \mathrm{~m}$ with an $11 \mathrm{~cm}$ culm diameter, and is a much larger cultivar of the common black bamboo species whose culms do not turn black. It is cold hardy down to $-20^{\circ} \mathrm{C}$, has dense dark green foliage and a gray waxy film on many culms that makes this species a striking ornamental plant. It also has straight, strong culms that make it useful for construction purposes. 1, 2, and 4.5-year-old samples of this bamboo species were obtained. 


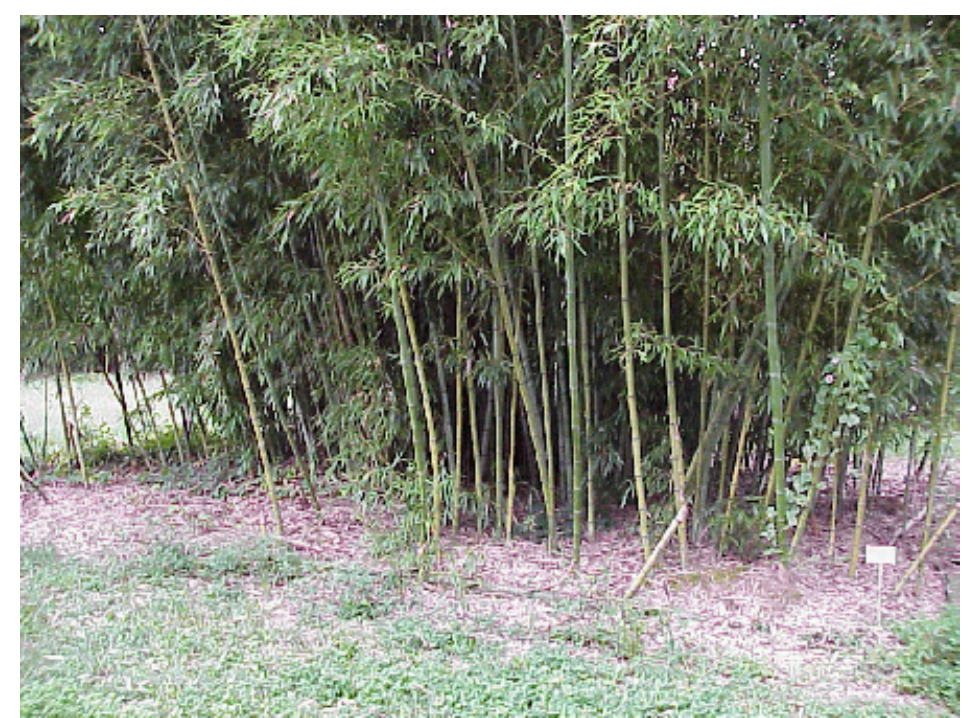

Figure 2. Stand (clonal repository) of Phyllostachys nigra, cultivar Henon, at the USDA-ARS/ University of Georgia Plant Genetic Resources Conservation Unit in Griffin, Georgia, USA. Maximum culm diameter is about $11 \mathrm{~cm}$, although this size has not been achieved in the stand pictured. Photograph taken August 1999 by G.R. Lovell, Bamboo Curator.

Phyllostachys bambusoides, cultivar White Crookstem (Figure 1): Rhizomes were collected near Yeunguk in the Lungtau Mountains of the Peoples Republic of China in 1926 by F.A. McClure, an agricultural explorer with the U.S. Bureau of Plant Industry. This monopodial bamboo grows to a maximum height of $11 \mathrm{~m}$ with a $5 \mathrm{~cm}$ culm diameter, and is cold hardy to $-18^{\circ} \mathrm{C}$. This cultivar differs from the common form in having culms that are curved in a serpentine manner at the base. It also has deposits of white powder on the culms which persists and often completely obscures the green color in older culms. 1, 2, and 4.5-year-old samples of this bamboo species were obtained.

Phyllostachys bissetii (Figure 3): Rhizomes were collected from Szechuan Province, Peoples Republic of China, in 1941 by John Tee-Van of the New York Zoological Society. This bamboo grows to a maximum height of $7 \mathrm{~m}$ with a $2.5 \mathrm{~cm}$ culm diameter. With a cold hardiness of $-23^{\circ} \mathrm{C}$, it is one of the most cold hardy samples cultivated by the USDA-ARS, and is the first to send up shoots in the spring - it is also the fastest growing and the most invasive. This bamboo is named after D. Bisset, the Superintendent of the USDA Plant Introduction Station at Savannah, Georgia, from 1924 to 1957. 1, 2, and 4-year-old samples of this bamboo species were obtained.

\subsection{Sample Preparation}

The following preparation was performed to obtain samples which were representative of each bamboo stand. Each of the nine bamboo samples comprised 6-9 representative culms with 2-3 nodes. Culms were split into pieces $1.3 \mathrm{~cm}$ wide using a knife or wood chisel, and cut into blocks about $7.5 \mathrm{~cm}$ long to facilitate milling. Approximately one half of each sample was processed whole, meaning that the nodes and internodes were milled together. The other half of the sample was separated into node samples and 


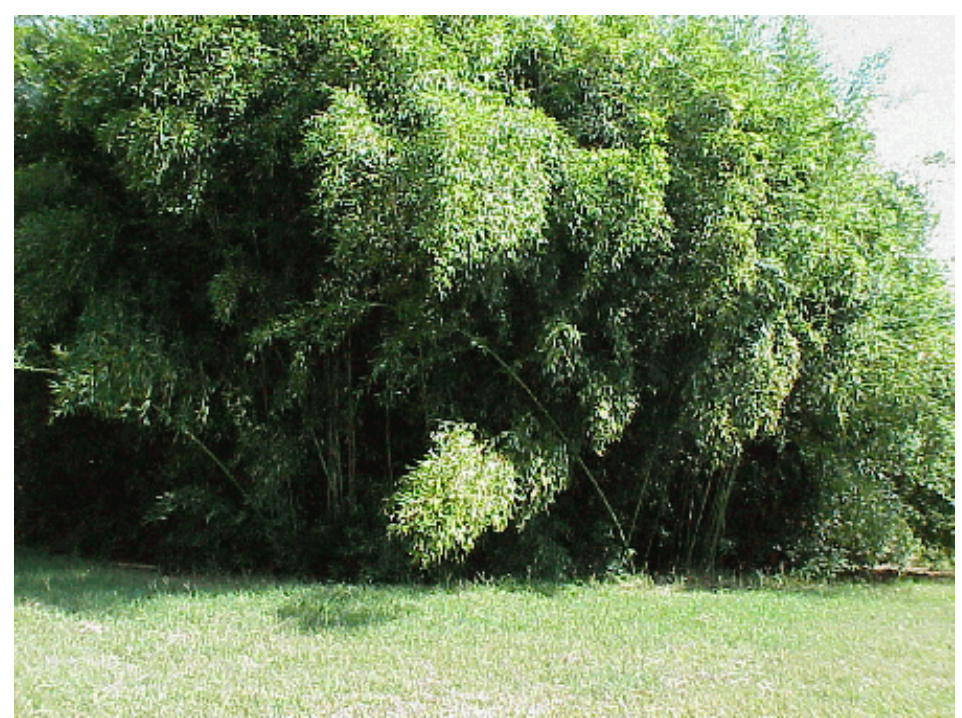

Figure 3. Stand (clonal repository) of Phyllostachys bissetii at the USDA-ARS/ University of Georgia Plant Genetic Resources Conservation Unit in Griffin, Georgia, USA. Culm diameter is about $2.5 \mathrm{~cm}$. Photograph taken August 1999 by G.R. Lovell, Bamboo Curator.

internode samples prior to milling. The node samples included the complete node plus less than one inch of culm on either side of the node. Each internode sample contained all of the pieces of culm not used in the node sample. Overall, 27 analyses were performed, representing whole bamboo, nodes and internodes for each of the 9 samples listed earlier. Milling and homogenization was performed to assure that the chemical analysis was performed on material which represented that average of each sample. Samples were milled using a Standard Whiley knife mill with a $2 \mathrm{~mm}$ screen. Material $<2 \mathrm{~mm}$ was sieved for 5 minutes using a 20 mesh sieve. Any material $>20$ mesh was milled until it passed the 20 mesh screen. The $<20$ mesh material was homogenized by cone and quartering four times.

\subsection{Fuel Analyses}

The proximate, ultimate and elemental ash analyses for the nine bamboo samples collected for this study are summarized in Table 1. The moisture contents of the samples ranged from 8-23\% with no correlation between the amount of moisture and the sample or the age of the sample. The moisture content of the $P$. nigra and $P$. bissetii samples increased with age of the harvested plant, while the moisture content of the $P$. bambusoides sample decreased as the age of the harvested plant increased. The ash contents of all of the bamboo samples were $1 \%$ or less and no correlation between ash content and bamboo sample or age of sample was apparent. Compared to other biomass feedstocks, these ash contents are comparable to what is found in woody biomass materials. Many herbaceous biomass materials, grasses and straws have higher ash contents. The volatiles content of the bamboo samples ranged from $63-75 \%$ with no correlation between volatiles content and bamboo sample or sample age. The remainder of the bamboo samples was fixed carbon. The fixed carbon content of the bamboo samples ranged from 12-17\% of the samples "as received". All of the bamboo samples had very similar higher heating values, ranging from 19.09-19.57 GJ/t on a dry basis (Tables 1 and 2). These heating values are comparable to, but slightly lower than, most woody biomass feedstocks and higher than most grasses and straws (Nordin, 1994). The carbon and hydrogen contents of the bamboo samples were all very similar, at about $52 \% \mathrm{C}$ and $5 \% \mathrm{H}$. The variation in the nitrogen content of the bamboo samples was larger, ranging from $0.2-0.5 \%$. From a combustion 
perspective, this is a very low $\mathrm{N}$ content and would be beneficial in terms of minimal fuel-bound nitrogen conversion to $\mathrm{NO}_{\mathrm{x}}$ if bamboo were used as a boiler fuel. If bamboo were used as a cofiring fuel, this could offset some of the input fuel-bound $\mathrm{N}$, because the bamboo samples tested here had lower $\mathrm{N}$ contents than many coals used for power production. Co-firing with bamboo may also have other $\mathrm{NO}_{\mathrm{x}}$ benefits caused by differences in flame structure and temperature that reduce thermal $\mathrm{NO}_{\mathrm{x}}$ formation. Likewise, the sulfur content of the bamboo samples is very low compared to coal, and like many woody biomass materials, is also lower than many herbaceous biomass feedstocks, grasses, and straws (Tables 1 and 2). Changes in the $\% \mathrm{C}, \% \mathrm{H}, \% \mathrm{~N}$, and $\% \mathrm{~S}$ do not correlate with the different bamboo samples or maturity of the samples.

There does appear to be some variation in the composition of the ash between each of the bamboo samples and with the maturity of the individual species. The silicon content of the $P$. nigra samples appears to increase with the maturity of the sample and while the overall ash content of the 4.5-year-old P. nigra is lower than the younger samples, the silicon content of the ash is greater by a factor of 4 . A similar increase in ash silicon content is also observed for the $P$. bisetii samples, and a more gradual increase for the $P$. bambusoides samples. The aluminum content of all the bamboo samples is very similar and in all cases the amount of titanium in the samples was below the detection limits of the measurements. The iron oxide contents of the bamboo samples are also quite low. The amount of alkaline earth oxides, $\mathrm{CaO}$ and $\mathrm{MgO}$, in the bamboo samples appears to increase as the bamboo plants mature. This is evident for all three samples. Conversely, the amount of alkali metal oxides appears to decrease as the bamboo plants mature. The amount of $\mathrm{K}_{2} \mathrm{O}$ in the bamboo ashes ranges from 30-50\%, however, the overall ash contents of the bamboo samples is low and this amounts to only $0.2-0.6 \% \mathrm{~K}_{2} \mathrm{O}$ in the dry samples. The phosphorus content of the bamboo ashes is relatively high, however, given the low ash contents of the samples the phosphorus content of the dry materials ranges form $0.1-0.2 \%$. The percentage of phosphorus in the bamboo ash appears to increase as the bamboo plants mature.

The low ash and chlorine contents of the bamboo samples make them attractive for use in biomass combustion applications for electricity production. As a feedstock for combustion applications, the potassium contents of these bamboo samples are also quite low. In fact, the alkali index of these samples (defined as $\mathrm{kg}$ alkali oxide per GJ energy content) ranges from $0.1-0.3$, generally below the empirical limit of 0.17-0.34 kg/GJ known to cause adverse fouling and slagging in combustion systems (Miles et al, 1996; Baxter et al., 1998). Chlorine in biomass has been shown to increase the volatility of alkali metals during combustion (Dayton and Milne, 1996), and the low chlorine content of the bamboo samples suggests that the potassium that is present is unlikely to be volatile, and therefore not problematic in terms of ash deposition. The low chlorine content of the bamboo samples means that burning them is unlikely to enhance high temperature corrosion in biomass combustion systems. 
Table 1. Fuel analyses for selected bamboo samples

\begin{tabular}{|c|c|c|c|c|c|c|c|c|c|}
\hline & \multicolumn{3}{|c|}{ Phyllostachys nigra } & \multicolumn{3}{|c|}{ Phyllostachys bambusoides } & \multicolumn{3}{|c|}{ Phyllostachys bissetti } \\
\hline \multicolumn{10}{|c|}{ Proximate Analysis ( $\%$ as received) } \\
\hline Moisture & 8.42 & 8.79 & 13.62 & 22.61 & 12.92 & 9.54 & 8.52 & 10.66 & 21.97 \\
\hline Ash & 0.86 & 0.87 & 0.41 & 0.66 & 0.84 & 0.53 & 1.14 & 0.78 & 0.9 \\
\hline Volatiles & 73.94 & 73.66 & 72.27 & 62.93 & 70.51 & 75.55 & 73.18 & 72.24 & 64.99 \\
\hline Fixed Carbon & 16.78 & 16.68 & 13.7 & 13.8 & 15.73 & 14.38 & 17.16 & 16.32 & 12.14 \\
\hline \multicolumn{10}{|c|}{ Higher Heating Value (GJ/t dry basis) } \\
\hline Alkali Index $(\mathrm{k}$ & \multicolumn{7}{|c|}{ Alkali Index (kg alkali oxide/GJ) } & 19.50 & 19.51 \\
\hline & \multicolumn{8}{|c|}{ Ultimate Analysis (\% dry matter) } & 0.20 \\
\hline $\mathrm{C}$ & 51.89 & 51.19 & 51.39 & 52.28 & 51.84 & 50.85 & 51.22 & 51.7 & 51.07 \\
\hline $\mathrm{H}$ & 5.21 & 5.29 & 5.25 & 5.09 & 5.18 & 5.40 & 4.90 & 5.00 & 4.51 \\
\hline $\mathrm{N}$ & 0.4 & 0.29 & 0.21 & 0.59 & 0.6 & 0.38 & 0.55 & 0.3 & 0.32 \\
\hline $\mathrm{S}$ & 0.04 & 0.03 & 0.03 & 0.05 & 0.05 & 0.04 & 0.05 & 0.03 & 0.05 \\
\hline $\mathrm{Cl}$ & 0.19 & 0.14 & 0.05 & 0.06 & 0.06 & 0.04 & 0.07 & 0.03 & 0.06 \\
\hline Ash & 0.94 & 0.95 & 0.47 & 0.85 & 0.96 & 0.59 & 1.25 & 0.87 & 1.15 \\
\hline $\mathrm{O}^{*}$ & 41.52 & 42.12 & 42.61 & 41.10 & 41.33 & 42.75 & 41.98 & 42.11 & 42.91 \\
\hline \multicolumn{10}{|c|}{ Ash Elemental $* *$ ( $\%$ dry matter) } \\
\hline $\mathrm{SiO}_{2}$ & 0.045 & 0.046 & 0.077 & 0.039 & 0.047 & 0.045 & 0.057 & 0.061 & 0.158 \\
\hline $\mathrm{Al}_{2} \mathrm{O}_{3}$ & 0.004 & 0.005 & 0.002 & 0.004 & 0.004 & 0.003 & 0.005 & 0.004 & 0.011 \\
\hline $\mathrm{TiO}_{2}$ & 0.000 & 0.000 & 0.000 & 0.000 & 0.000 & 0.000 & 0.000 & 0.000 & 0.000 \\
\hline $\mathrm{Fe}_{2} \mathrm{O}_{3}$ & 0.019 & 0.002 & 0.002 & 0.004 & 0.002 & 0.002 & 0.002 & 0.002 & 0.006 \\
\hline $\mathrm{CaO}$ & 0.015 & 0.018 & 0.024 & 0.018 & 0.021 & 0.037 & 0.029 & 0.024 & 0.073 \\
\hline $\mathrm{MgO}$ & 0.021 & 0.023 & 0.031 & 0.027 & 0.030 & 0.075 & 0.045 & 0.041 & 0.076 \\
\hline $\mathrm{Na}_{2} \mathrm{O}$ & 0.003 & 0.001 & 0.003 & 0.003 & 0.000 & 0.001 & 0.002 & 0.001 & 0.002 \\
\hline $\mathrm{K}_{2} \mathrm{O}$ & 0.415 & 0.475 & 0.158 & 0.378 & 0.411 & 0.180 & 0.578 & 0.371 & 0.382 \\
\hline $\mathrm{P}_{2} \mathrm{O}_{5}$ & 0.130 & 0.105 & 0.097 & 0.125 & 0.180 & 0.123 & 0.155 & 0.107 & 0.181 \\
\hline $\mathrm{SO}_{3}$ & 0.028 & 0.024 & 0.011 & 0.018 & 0.022 & 0.019 & 0.052 & 0.025 & 0.033 \\
\hline $\mathrm{Cl}$ & 0.034 & 0.027 & 0.003 & 0.009 & 0.008 & 0.002 & 0.025 & 0.006 & 0.007 \\
\hline $\mathrm{CO}_{2}$ & 0.072 & 0.112 & 0.016 & 0.060 & 0.062 & 0.028 & 0.129 & 0.094 & 0.056 \\
\hline Undetermined & 0.155 & 0.110 & 0.046 & 0.166 & 0.174 & 0.075 & 0.171 & 0.133 & 0.166 \\
\hline \multicolumn{10}{|c|}{ Ash Elemental (\% ash, $\left.600^{\circ} \mathrm{C}\right)$} \\
\hline $\mathrm{SiO}_{2}$ & 4.74 & 4.89 & 16.30 & 4.61 & 4.87 & 7.64 & 4.52 & 7.04 & 13.74 \\
\hline $\mathrm{Al}_{2} \mathrm{O}_{3}$ & 0.40 & 0.56 & 0.42 & 0.42 & 0.42 & 0.48 & 0.43 & 0.49 & 0.99 \\
\hline $\mathrm{TiO}_{2}$ & $<0.01$ & $<0.01$ & $<0.01$ & $<0.01$ & $<0.01$ & $<0.01$ & $<0.01$ & $<0.01$ & $<0.01$ \\
\hline $\mathrm{Fe}_{2} \mathrm{O}_{3}$ & 2.06 & 0.23 & 0.42 & 0.43 & 0.16 & 0.39 & 0.16 & 0.25 & 0.48 \\
\hline $\mathrm{CaO}$ & 1.59 & 1.90 & 5.06 & 2.17 & 2.17 & 6.34 & 2.33 & 2.74 & 6.35 \\
\hline $\mathrm{MgO}$ & 2.22 & 2.44 & 6.66 & 3.12 & 3.10 & 12.70 & 3.62 & 4.71 & 6.62 \\
\hline $\mathrm{Na}_{2} \mathrm{O}$ & 0.27 & 0.15 & 0.71 & 0.35 & $<0.01$ & 0.21 & 0.16 & 0.10 & 0.19 \\
\hline $\mathrm{K}_{2} \mathrm{O}$ & 44.20 & 50.00 & 33.60 & 44.50 & 42.80 & 30.50 & 46.20 & 42.70 & 33.20 \\
\hline $\mathrm{P}_{2} \mathrm{O}_{5}$ & 13.80 & 11.02 & 20.70 & 14.69 & 18.74 & 20.80 & 12.36 & 12.25 & 15.71 \\
\hline $\mathrm{SO}_{3}$ & 2.94 & 2.51 & 2.32 & 2.13 & 2.27 & 3.18 & 4.17 & 2.93 & 2.83 \\
\hline $\mathrm{Cl}$ & 3.63 & 2.87 & 0.59 & 1.10 & 0.84 & 0.26 & 2.03 & 0.65 & 0.58 \\
\hline $\mathrm{CO}_{2}$ & 7.68 & 11.83 & 3.42 & 7.00 & 6.47 & 4.77 & 10.35 & 10.83 & 4.89 \\
\hline Undetermined & 16.47 & 11.60 & 9.80 & 19.48 & 18.16 & 12.73 & 13.67 & 15.31 & 14.42 \\
\hline
\end{tabular}


Table 2. Comparison of selected fuel properties of bamboo with other bioenergy crops

\begin{tabular}{|c|c|c|c|c|c|}
\hline Fuel property & $\begin{array}{l}\text { Bamboo } \\
\text { (range of three } \\
\text { Phyllostachys } \\
\text { species) }\end{array}$ & $\begin{array}{l}\text { "Bamboo" } \\
\text { (species not } \\
\text { given) })^{\text {b }}\end{array}$ & $\begin{array}{l}\text { "Bamboo" } \\
\text { (species not } \\
\text { given) }{ }^{c}\end{array}$ & $\begin{array}{l}\text { Miscanthus } \\
\text { (Miscanthus } x_{\text {giganteus }^{\mathrm{d}}}\end{array}$ & $\begin{array}{l}\text { Switchgrass } \\
\text { (Panicum }^{\text {virgatum })^{\mathrm{e}}}\end{array}$ \\
\hline $\begin{array}{l}\text { Gross heating } \\
\text { value } \\
(\text { dry; GJ/t) }\end{array}$ & $19.1-19.6$ & 15.85 & 18.96 & $17.1-19.4$ & 18.3 \\
\hline $\begin{array}{l}\text { Moisture content } \\
(\%)\end{array}$ & $\begin{array}{l}8.4-22.6 \\
\text { (samples as } \\
\text { received after } \\
\text { shipping) }\end{array}$ & $\begin{array}{l}10.4 \\
\text { (at harvest?) }\end{array}$ & $\begin{array}{l}2.94 \\
\text { (after drying?) }\end{array}$ & $\begin{array}{l}15 \\
\text { (at harvest) }\end{array}$ & $\begin{array}{l}15 \\
\text { (at harvest) }\end{array}$ \\
\hline Ash content (\%) & $<1.0$ & 3.98 & 2.04 & $1.5-4.5$ & $4.5-5.8$ \\
\hline $\begin{array}{l}\text { Sulfur content } \\
(\%)\end{array}$ & $0.03-0.05$ & N/A & 0.15 & 0.1 & 0.12 \\
\hline
\end{tabular}

aPresent study

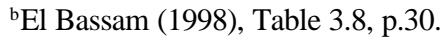

${ }^{\mathrm{c} C}$ C.E. Pugh, 1981, laboratory report for Northeast Louisiana University, cited in Woods (1996)

${ }^{\mathrm{d}}$ Data for miscanthus from Scurlock (1999)

eData for switchgrass from McLaughlin et al. (1996)

See also Nordin (1994) for a review of bioenergy fuel characteristics.

\subsection{Wet Chemical Analysis}

All bamboo samples were analyzed using American Society for Testing and Materials (ASTM) standard methods for whole biomass analysis, as listed below:

ASTM E1690 Test Method for the Determination of Ethanol Extractives in Biomass

ASTM E1721 Test Method for the Determination of Acid Insoluble Residue in Biomass.

ASTM E1756 Test Method for the Determination of Total Solids in Biomass

ASTM E1757 Preparation of Biomass for Compositional Analysis

ASTM E1758 Standard Method for Determination of Carbohydrates in Biomass by High Performance

Liquid Chromatography.

U.S. National Institute of Standards and Technology (NIST) Bagasse Standard Reference Material \# 8491 was analyzed with each batch of bamboo samples, as a quality-assurance reference for the determination of extractives, lignin and carbohydrates. Aqueous and ethanolic extractions were performed in duplicate on the milled, homogenized samples. Each extractives-free sample was analyzed in duplicate for lignin and carbohydrate content, giving a total of four separate determinations for each bamboo sample.

Table 3 shows the complete wet chemical analysis of the 27 bamboo samples. Total mass closure for all samples was greater than $99 \%$, indicating that the analysis is complete and no significant biomass fractions were excluded. The values obtained are similar to those reported by Higuchi (1957) for samples of mature bamboo (Table 4). Direct measurement of the protein content of these samples was not performed, but the protein content can be estimated from the nitrogen elemental analysis (Phillips, 1939) and varies only 
slightly with age in the range $1.4-3.8 \%$. Interference from acid-insoluble protein may introduce a slight additional error in the lignin analysis. The lignin values of 25-30\% place bamboo at the high end of the normal range of 11-27\% reported for non-woody biomass (Bagby et al., 1971), and more closely resemble the ranges reported for softwoods (24-37\%) and hardwoods (17-30\%) (Fengel and Wegner, 1984; Dence, 1992). This would suggest that bamboo should have similar physical properties and uses to conventional softwoods and hardwoods (Panshin and de Zeeuw 1980). Indeed, its high lignin content contributes to the relatively high heating value of bamboo, and its structural rigidity makes it a valuable building material. Similarly, the glucan contents of 40-48\% compare to the reported cellulose content of softwoods (40-52\%) and hardwoods (38-56\%). Cellulose contents in this range make bamboo a useful feedstock for paper production and for processes which convert cellulose to fuels, chemicals and other bio-based materials.

The average and standard deviation of 27 independent analyses of the standard reference material are shown at the foot of Table 3 . The reproducibility and total mass closure indicate the precision that can reasonably be expected from these methods of analysis. Differences between bamboo samples smaller than the standard deviation of the reference material will not be significant. The average total mass closure for the NIST bagasse reference samples was $99.5 \pm 1.2 \%$, indicating that no significant biomass fractions were excluded from the analysis.

The lignin, glucan and xylan contents all showed variances with age comparable to the 1-5\% reported for softwood (Panshin and de Zeeuw, 1980). There is a slight trend toward lower lignin with increased age (Table 3), although it is only significant in the 4 and 4.5 year old bamboo samples. This trend is confirmed by a slight increase in the independently determined glucan content. These changes occur in both the node and internode fractions, being only slightly more pronounced in the internode segments. However, the magnitude of the compositional differences is small and is not expected to result in significant variations in heating value or physical properties.

Differences between the composition of node and internode fractions are also small, 1-4\%, and compare to those reported for the natural variance in wood (Panshin and de Zeeuw, 1980). The small differences in chemical composition between node and internode samples for these bamboo samples suggest that neither the number of nodes nor the length of internode segments would be critical to the utilization of bamboo for energy conversion, chemical production or as a building material (Table 3 ). 
Table 3. Wet chemical analysis of selected bamboo samples

\begin{tabular}{|c|c|c|c|c|c|c|c|c|c|c|}
\hline Sample & Fraction & $\begin{array}{c}\% \\
\text { ash }\end{array}$ & $\begin{array}{l}\% \text { Ethanol } \\
\text { Extractives }\end{array}$ & $\begin{array}{l}\% \text { Total } \\
\text { Lignin }\end{array}$ & $\%$ Glucan & $\begin{array}{c}\% \\
\text { Xylan }\end{array}$ & $\begin{array}{c}\% \\
\text { Mannan }\end{array}$ & $\begin{array}{c}\% \\
\text { Arabinan }\end{array}$ & $\begin{array}{c}\% \\
\text { Galactan }\end{array}$ & Total \\
\hline P. bissetii $1 \mathrm{yr}$ & whole & 1.2 & 1.4 & 28.2 & 42.2 & 24.0 & 0.5 & 1.1 & 1.1 & 99.7 \\
\hline P. bissetii $1 \mathrm{yr}$ & nodes & 0.6 & 2.1 & 28.5 & 41.9 & 24.5 & 0.0 & 2.1 & 2.1 & 101.8 \\
\hline P. bissetii $1 \mathrm{yr}$ & internodes & 1.4 & 1.6 & 27.9 & 43.7 & 24.6 & 0.5 & 1.0 & 1.0 & 101.8 \\
\hline P. bissetii 2 yrs & whole & 1.0 & 3.1 & 27.9 & 40.7 & 23.6 & 0.6 & 1.1 & 1.2 & 99.2 \\
\hline P. bissetii 2 yrs & nodes & 0.7 & 1.9 & 28.4 & 42.3 & 25.7 & 0.0 & 2.0 & 2.1 & 103.1 \\
\hline P. bissetii 2 yrs & internodes & 0.9 & 1.5 & 28.3 & 43.6 & 25.9 & 0.5 & 1.0 & 1.0 & 102.7 \\
\hline P. bissetii 4 yrs & whole & 1.2 & 2.2 & 27.1 & 41.9 & 22.8 & 0.8 & 1.2 & 1.2 & 98.3 \\
\hline P. bissetii 4 yrs & nodes & 0.8 & 3.0 & 27.0 & 41.3 & 23.3 & 0.0 & 2.0 & 2.0 & 102.3 \\
\hline P. bissetii 4 yrs & internodes & 1.1 & 1.4 & 26.2 & 47.2 & 24.1 & 0.4 & 1.1 & 1.1 & 102.7 \\
\hline average & & 1.0 & 2.0 & 27.7 & 42.8 & 24.3 & 0.4 & 1.4 & 1.4 & 101.3 \\
\hline standard deviation & & 0.3 & 0.6 & 0.8 & 1.9 & 1.0 & 0.3 & 0.5 & 0.5 & 1.7 \\
\hline P. bambusoides $1 \mathrm{yr}$ & whole & 0.9 & 2.0 & 26.8 & 41.8 & 24.1 & 0.8 & 1.2 & 1.3 & 99.0 \\
\hline P. bambusoides $1 \mathrm{yr}$ & nodes & 0.3 & 1.8 & 27.0 & 40.9 & 23.9 & 0.7 & 1.3 & 1.3 & 97.3 \\
\hline P. bambusoides $1 \mathrm{yr}$ & internodes & 1.3 & 1.6 & 26.2 & 44.5 & 26.0 & 0.5 & 1.1 & 1.1 & 102.3 \\
\hline P. bambusoides 2 yrs & whole & 0.9 & 1.9 & 26.8 & 40.8 & 24.1 & 0.7 & 1.2 & 1.2 & 97.5 \\
\hline P. bambusoides 2 yrs & nodes & 0.4 & 1.6 & 27.4 & 40.3 & 24.9 & 0.8 & 1.3 & 1.4 & 98.0 \\
\hline P. bambusoides 2 yrs & internodes & 1.3 & 1.3 & 26.2 & 44.4 & 27.0 & 0.4 & 1.2 & 1.2 & 102.9 \\
\hline P. bambusoides $4.5 \mathrm{yrs}$ & whole & 0.6 & 1.1 & 25.5 & 44.9 & 24.0 & 0.6 & 1.3 & 1.3 & 99.3 \\
\hline P. bambusoides $4.5 \mathrm{yrs}$ & nodes & 0.2 & 1.5 & 25.3 & 44.0 & 23.3 & 0.8 & 1.3 & 1.4 & 97.8 \\
\hline P. bambusoides 4.5 yrs & internodes & 0.8 & 1.1 & 24.3 & 48.1 & 24.0 & 0.5 & 1.1 & 1.1 & 101.0 \\
\hline average & & 0.7 & 1.5 & 26.2 & 43.3 & 24.6 & 0.6 & 1.2 & 1.3 & 99.4 \\
\hline standard deviation & & 0.4 & 0.3 & 1.0 & 2.6 & 1.2 & 0.2 & 0.1 & 0.1 & 2.1 \\
\hline P. nigra $1 \mathrm{yr}$ & whole & 0.8 & 2.3 & 28.3 & 41.3 & 24.4 & 0.5 & 1.4 & 1.4 & 100.4 \\
\hline P. nigra $1 \mathrm{yr}$ & nodes & 0.2 & 1.7 & 27.9 & 40.7 & 23.1 & 0.7 & 1.4 & 1.5 & 97.2 \\
\hline P. nigra $1 \mathrm{yr}$ & internodes & 0.1 & 1.7 & 28.6 & 41.3 & 24.0 & 0.5 & 1.4 & 1.4 & 99.0 \\
\hline P. nigra 2 yrs & whole & 0.8 & 2.2 & 27.8 & 42.7 & 24.2 & 0.6 & 1.2 & 1.2 & 100.7 \\
\hline P. nigra $2 \mathrm{yrs}$ & nodes & 0.9 & 1.4 & 27.9 & 42.8 & 24.6 & 0.6 & 1.3 & 1.3 & 100.7 \\
\hline P. nigra 2 yrs & internodes & 0.6 & 1.6 & 27.5 & 43.1 & 23.4 & 0.5 & 1.2 & 1.2 & 99.0 \\
\hline P. nigra $4.5 \mathrm{yrs}$ & whole & 0.4 & 1.9 & 25.2 & 46.4 & 23.0 & 0.6 & 1.1 & 1.1 & 99.7 \\
\hline P. nigra $4.5 \mathrm{yrs}$ & nodes & 0.4 & 1.6 & 25.5 & 46.0 & 24.0 & 0.6 & 1.2 & 1.2 & 100.6 \\
\hline P. nigra 4.5 yrs & internodes & 0.2 & 1.5 & 25.5 & 46.2 & 22.9 & 0.5 & 1.1 & 1.2 & 99.1 \\
\hline average & & 0.5 & 1.8 & 27.1 & 43.4 & 23.7 & 0.6 & 1.3 & 1.3 & 99.6 \\
\hline standard deviation & & 0.3 & 0.3 & 1.3 & 2.3 & 0.6 & 0.1 & 0.1 & 0.1 & 1.2 \\
\hline \multicolumn{11}{|c|}{ NIST reference material \#8491 (bagasse) } \\
\hline average & & 1.8 & 4.4 & 23.1 & 41.7 & 24.7 & 0.7 & 1.6 & 1.6 & 99.5 \\
\hline standard deviation & & 0.3 & 1.0 & 0.5 & 1.2 & 0.9 & 0.1 & 0.2 & 0.2 & 2.0 \\
\hline
\end{tabular}


Table 4. Previous chemical analysis of bamboo

\begin{tabular}{|c|c|c|c|c|c|c|}
\hline & $\%$ ash & $\begin{array}{c}\% \text { Ethanol- } \\
\text { benzene } \\
\text { extractives }\end{array}$ & $\%$ Lignin & $\%$ Cellulose & $\%$ Pentosan & Total \\
\hline \multicolumn{7}{|l|}{ Species } \\
\hline Phyllostachys heterocycla & 1.3 & 4.6 & 26.1 & 49.1 & 27.7 & 108.82 \\
\hline P. nigra & 2.0 & 3.4 & 23.8 & 42.3 & 24.1 & 95.61 \\
\hline$P$. reticulata & 1.9 & 3.4 & 25.3 & 41.0 & 26.5 & 98.15 \\
\hline
\end{tabular}

Data from Higuchi (1957)

\section{Stand Establishment and Management}

Since most bamboos flower very infrequently, plantation stands are usually established from vegetative material rather than from seedlings, although the latter approach is a possibility. Rhizome propagation involves cutting 30-50 cm lengths of rhizomes, 1-2 years old with nodes and buds present - however, low multiplication rates make it difficult to establish large plantations by this method (El Bassam, 1998). Older rhizomes, with fewer roots and buds present, do not propagate well (Sturkie et al., 1968). Adamson et al. (1978) used existing farm machinery (ploughs, etc.) to propagate bamboo from nursery fields. Rows of 2year-old bamboo were cut at a height of about 2 feet $(60 \mathrm{~cm})$, the rhizomes dug up with a turning plough, and then the plants separated by hand. February (early spring in the U.S. South-East) was the optimum time for propagating. Propagating from entire plants (about 6 nodes of stem material and a foot $(30 \mathrm{~cm})$ of attached rhizome) was more successful than propagating from rhizomes alone. Fertilization and weed control in nursery fields and young stands is desirable, but weed control with herbicides was preferable to disturbing the soil (Sturkie et al., 1968). Adamson et al. (1978) reported low multiplication rates (annual doubling): one hectare of 2-year-old nursery field was only enough to plant a 4-hectare stand. Traditional methods for propagation also include branch and stem cuttings and seedlings, where available

(IFAR/INBAR, 1991).

In India, tissue culture techniques have been used for the rapid large-scale production of planting stocks from selected vigorous seedlings of Dendrocalamus strictus (Nadgauda et al., 1997). Cultured seedlings of several bamboo species have also been induced to flower and seed precociously using cytokinins and control of $\mathrm{pH}$, suggesting that hybridization may be possible in the future. Nadgauda et al. (1997) review 34 published English-language reports of tissue culture in a variety of bamboo species.

Seven or eight years may be required after establishing a stand of tall bamboo before the culms are large enough and sufficiently "woody" to be harvested. Some weaker shoots may die back before reaching maturity. The ultimate stand height may not be achieved until 15-20 years (Sturkie et al., 1968). Adamson et al. (1978) agree that yields are likely to be low during an initial establishment period of up to 8 years.

Avoidance or control of flowering may comprise an important but yet undeveloped aspect of management, since this generally results in the die-back of entire stands. A few rhizome buds may remain viable, but the re-establishment of a new stand from surviving rhizomes or from seed would be required over the course of following 5-10 years. Bamboo re-growing after seeding requires thinning and selection of the strongest shoots (Sturkie et al., 1968). 
Recommended fertilizer levels based on Dendrocalamus trials in India (cited in El Bassam, 1998) are N:P:K 100:50:50 kg/ha, similar to the levels suggested below by Sturkie et al. (1968). Fertilization at the beginning of the growing season can result in up to a three-fold increase in above-ground productivity (El Bassam, 1998).

Harvesting of traditionally-grown bamboo is un-mechanized and labor-intensive. Traditionally, only the most mature poles (about 8 years old) are removed selectively, although it is feasible to harvest a range of ages of poles, sorting them later on the basis of density. Research in India suggests that clear-cutting does not significantly damage bamboo stands (El Bassam, 1998), so it may be possible to use machinery such as modified sugar-cane harvesters.

Some problems have been reported in restricting the spread of hardy monopodial bamboos (Sturkie et al., 1968).

\section{Productivity of Bamboo in Asia and South America}

As was suggested in Section 2 above, literature on bamboo productivity is scarce, with most reports coming from various parts of Asia. All the data reviewed here are reported as oven-dry biomass, and are summarized in Table 5.

Above-ground net primary productivity (ANPP), including leaf turnover, for Phyllostachys bambusoides in central Japan (latitude $35^{\circ} \mathrm{N}$ ) was reported at 24.6 t/ha/year over a 6-year period (Isagi et al., 1993).

Woody biomass increment, excluding leaf turnover, was $15.5 \mathrm{t} / \mathrm{ha} / \mathrm{year}$. Above-ground biomass of this mature stand (which last flowered 16-22 years previously) was $131 \mathrm{t} / \mathrm{ha}$, of which $112 \mathrm{t} / \mathrm{ha}$ comprised culms. A related study on Phyllostachys pubescens in Japan found ANPP of $18.1 \mathrm{t} / \mathrm{ha} / \mathrm{year}$; although total NPP was high (33 t/ha/year), allocation to roots and rhizomes was substantial (Isagi et al., 1997). Aboveground biomass of this mature stand (age not given) was $138 \mathrm{t} / \mathrm{ha}$ (117 t/ha in culms).

Above-ground woody biomass increments averaging 7.7 t/ha/year (8.8 and 6.6 t/ha/year in 1986 and 1987, respectively) are reported for a semi-natural lowland stand of Phyllostachys pubescens in Zhejiang Province, China (latitude $30^{\circ} \mathrm{N}$; elevation $100 \mathrm{~m}$; mean annual temperature and rainfall, $16^{\circ} \mathrm{C}$ and 1800 $\mathrm{mm})$. This mature stand, which was subject to harvesting of poles over 8 years old, had an above-ground biomass of $56 \mathrm{t} / \mathrm{ha}$, and a maximum height of 15-20 m (Qiu et al., 1992). 
Table 5. Reported maximum above-ground productivity of bamboo stands

\begin{tabular}{|c|c|c|c|c|c|}
\hline $\begin{array}{l}\text { Location (latitude, } \\
\text { where available) }\end{array}$ & $\begin{array}{l}\text { Mean annual } \\
\text { temperature } \\
\text { and } \\
\text { precipitation, } \\
\text { where } \\
\text { available }\end{array}$ & $\begin{array}{l}\text { Total ANPP* } \\
\text { (maximum } \\
\text { figure } \\
\text { reported); } \\
\text { t/ha/year }\end{array}$ & $\begin{array}{l}\text { Above-ground } \\
\text { wood } \\
\text { productivity } \\
\text { (average } \\
\text { reported); } \\
\text { t/ha/year }\end{array}$ & $\begin{array}{l}\text { Special stand } \\
\text { features } \\
\text { (elevation, } \\
\text { management) and } \\
\text { other remarks }\end{array}$ & Reference \\
\hline $\begin{array}{l}\text { southern India } \\
\left(11^{\circ} \mathrm{N}\right)\end{array}$ & $\begin{array}{l}31^{\circ} \mathrm{C} ; 600 \\
\mathrm{~mm}\end{array}$ & 47.0 & N/A & $\begin{array}{l}\text { highland }(540 \mathrm{~m}) \text {; } \\
\text { fertilized and } \\
\text { irrigated }\end{array}$ & $\begin{array}{l}\text { Shanmughavel } \\
\text { and Francis } \\
\text { (1996) }\end{array}$ \\
\hline $\begin{array}{l}\text { central Japan } \\
\left(35^{\circ} \mathrm{N}\right)\end{array}$ & N/A & 24.6 & 15.5 & & $\begin{array}{l}\text { Isagi et al. } \\
\text { (1993) }\end{array}$ \\
\hline Japan & N/A & 18.1 & N/A & & $\begin{array}{l}\text { Isagi et al. } \\
\text { (1997) }\end{array}$ \\
\hline $\begin{array}{l}\text { Georgia, USA } \\
\left(32^{\circ} \mathrm{N}\right)\end{array}$ & & N/A & 9.1 & $\begin{array}{l}\text { "sustainable } \\
\text { yield" }\end{array}$ & $\begin{array}{l}\text { Adamson et al. } \\
\text { (1978) }\end{array}$ \\
\hline $\begin{array}{l}\text { central Chile } \\
\left(40^{\circ} \mathrm{S}\right)\end{array}$ & $4000 \mathrm{~mm}$ & 10.5 & 6.2 & montane $(700 \mathrm{~m})$ & $\begin{array}{l}\text { Veblen et al. } \\
\text { (1980) }\end{array}$ \\
\hline $\begin{array}{l}\text { Zhejiang, China } \\
\left(30^{\circ} \mathrm{N}\right)\end{array}$ & $\begin{array}{l}16^{\circ} \mathrm{C} ; 1800 \\
\mathrm{~mm}\end{array}$ & 10.5 & 7.7 & $\begin{array}{l}\text { managed by } \\
\text { harvesting }\end{array}$ & $\begin{array}{l}\text { Qiu et al. } \\
\text { (1992) }\end{array}$ \\
\hline $\begin{array}{l}\text { Alabama, USA } \\
\left(32^{\circ} \mathrm{N}\right)\end{array}$ & & N/A & 7.4 & $\begin{array}{l}\text { Probably } \\
\text { fertilized }\end{array}$ & $\begin{array}{l}\text { Sturkie et al. } \\
\text { (1968) }\end{array}$ \\
\hline Thailand $\left(14^{\circ} \mathrm{N}\right)$ & $\begin{array}{l}28^{\circ} \mathrm{C} ; 950 \\
\mathrm{~mm}\end{array}$ & 8.1 & N/A & & $\begin{array}{l}\text { Suwannapinunt } \\
\text { (1983) }\end{array}$ \\
\hline $\begin{array}{l}\text { northern India } \\
\left(25^{\circ} \mathrm{N}\right)\end{array}$ & $\begin{array}{l}26^{\circ} \mathrm{C} ; 830 \\
\mathrm{~mm}\end{array}$ & 7.7 & 2.2 & & $\begin{array}{l}\text { Tripathi and } \\
\text { Singh (1994) }\end{array}$ \\
\hline $\begin{array}{l}\text { central China } \\
\left(32^{\circ} \mathrm{N}\right)\end{array}$ & $1200 \mathrm{~mm}$ & 4.5 & 3.1 & $\begin{array}{l}\text { montane }(2750 \\
\text { m); ANPP* } \\
\text { figure corrected } \\
\text { for grazing }\end{array}$ & $\begin{array}{l}\text { Taylor and Qin } \\
\text { (1987) }\end{array}$ \\
\hline
\end{tabular}

*ANPP = above-ground net primary productivity

All data are reported as oven-dry biomass.

ANPP of Thyrsostachys siamensis in Thailand $\left(14^{\circ} \mathrm{N}\right.$; elevation $60 \mathrm{~m}$; mean annual temperature and rainfall, $28^{\circ} \mathrm{C}$ and $950 \mathrm{~mm}$ ) ranged from 1.6 to $8.1 \mathrm{t} / \mathrm{ha} /$ year according to site quality (mean $4.3 \mathrm{t} / \mathrm{ha} / \mathrm{year}$ ). Above-ground biomass of stands varied from 11 to $54 \mathrm{t} / \mathrm{ha}$, with a mean value of $32 \mathrm{t} / \mathrm{ha}$, and mean stand height ranged from 5.5 to $9.9 \mathrm{~m}$ (Suwannapinunt, 1983). 
A tropical plantation of Bambusa bambos in southern India (approx. $11^{\circ} \mathrm{N}$; elevation $540 \mathrm{~m}$; mean annual temperature and rainfall, $31^{\circ} \mathrm{C}$ and $600 \mathrm{~mm}$ ), grown from tissue culture stock with fertilization and irrigation, attained an above-ground biomass of $286 \mathrm{t} / \mathrm{ha}$ in its first 6 years. This is equivalent to an average above-ground productivity of 47 t/ha/year (Shanmughavel and Francis, 1996).

At a site in northern India (approx. $25^{\circ} \mathrm{N}$; mean annual temperature and rainfall, $26^{\circ} \mathrm{C}$ and $830 \mathrm{~mm}$ ), total NPP of Dendrocalamus strictus savanna was estimated at 15.8-19.3 t/ha/year. However, about half of total ecosystem NPP was accounted for by below-ground turnover, and after accounting for other woody and herbaceous species, above-ground woody biomass increment of bamboo was only $2.2 \mathrm{t} / \mathrm{ha} / \mathrm{year}$ for a mature stand and $1.1 \mathrm{t} / \mathrm{ha} /$ year for a recently-harvested stand (Tripathi and Singh, 1994).

Veblen et al. (1980) estimated the biomass and productivity of a stand of montane Chusquea culeou in Chile (latitude $39.5^{\circ} \mathrm{S}$, elevation 700m, annual rainfall $4000 \mathrm{~mm}$ ). ANPP was 10-11 t/ha/year, and aboveground biomass about $160 \mathrm{t} / \mathrm{ha}$, with a maximum stand height of about $9 \mathrm{~m}$. Lower productivities and biomass are reported for montane forest understorey bamboos in central China (approx. $32^{\circ} \mathrm{N}$ ) by Taylor and Qin (1987). Here, the most productive species, Fargesia spathacea (now renamed F. robusta), growing at 2500-3000 m elevation with annual rainfall of $1200 \mathrm{~mm}$, had ANPP of about $3.6 \mathrm{t} / \mathrm{ha}$ /year (or $4.5 \mathrm{t} / \mathrm{ha} /$ year, corrected for grazing losses to giant pandas). Above-ground biomass was nearly $24 \mathrm{t} / \mathrm{ha}$, with maximum stand height about 2.5-3.0 m.

El Bassam (1998) cites above-ground (air-dry) yields of native bamboo stands ranging from 1.5-2.5 t/ha/year for Thyrsostachys siamensis in Thailand to 10-14 t/ha/year for Phyllostachys bambusoides in Japan, and $18 \mathrm{t} / \mathrm{ha} / \mathrm{year}$ for managed trial plots of Dendrocalamus strictus in India.

\section{Limited Experience with Bamboo in the USA}

Since there is a paucity of literature on U.S. experience with bamboos, most of the available information has been gathered together in one section covering history, applications and productivity.

According to Sturkie et al. (1968) and Adamson et al. (1978) "oriental" bamboo was introduced to the U.S. in about 1860, and the former U.S. Department of Agriculture (USDA) collection at Savannah, Georgia, dates back to 1919. After a brief resurgence of interest in bamboo as a potential bioenergy crop during the 1970s, the Savannah station was closed around 1978, and the national collection (including 21 species of Phyllostachys and 17 other genera) is presently maintained at Byron, Georgia, with funding from the Agricultural Experiment Station at Griffin, Georgia (now the USDA Plant Genetic Resources Conservation Unit). The USDA concluded that many other crops would out-produce bamboo under the majority of U.S. conditions, and that most of the land not already used for food production in southern states such as Florida was unsuitable for bamboo. However, large-scale trials were never conducted (G.R. Lovell, pers. comm.).

Interest in bamboo as a crop in Alabama dates back to the rise of angling in the 1930s and attempts by local growers to meet the demand for fishing poles (Sturkie et al., 1968). Trial plots of bamboo were initiated at the Agricultural Experiment Station, Auburn, in 1933, using nursery materials from the U.S. Plant Introduction Station at Savannah, Georgia. Development of the south-eastern paper and pulp industry in the late 1950s and 1960s led to more extensive USDA trials at Camden, Alabama (latitude $32^{\circ} \mathrm{N}$ ), but these were discontinued in 1965. Bamboos found in Alabama include Bambusa sp. from the Gulf Coast, Phyllostachys sp. (introduced "Japanese bamboo") and the sole native Arundinaria sp. (sometimes described as two species; A. gigantea and A. tecta) which used to occur abundantly throughout the U.S. 
South-East in stands known as "cane-brakes". Some hardy bamboos are reported to grow as far north as Pennsylvania $\left(40-42^{\circ} \mathrm{N}\right)$, and Phyllostachys bambusoides is also known to grow in central northern California $\left(40^{\circ} \mathrm{N}\right)$.

In the early 1960s, the USDA evaluated the paper pulping characteristics of 21 bamboo species, including 5 tropical sympodial (clumped) bamboos from Puerto Rico (latitude $18^{\circ} \mathrm{N}$ ). All were found to be suitable for paper-making using either the Kraft or the Raitt processes, with long fibers (1.4-2.3 mm) (Adamson et al., 1978). Some experience with applications of bamboo also appears to have been obtained at the Engineering Experiment Station, Clemson College, South Carolina (quoted in Sturkie et al., 1968).

Sturkie et al. (1968) report a cumulative above-ground "yield" of $121 \mathrm{t} / \mathrm{ha}$ dry matter (48 t/acre) for Phyllostachys rubromarginata at Auburn, Alabama (latitude about $32^{\circ} \mathrm{N}$ ), for stands aged 14-20 years, or an average of 6.1-8.6 t/ha/year. These figures exclude leaf biomass, with branches accounting for $14 \%$ of above-ground dry matter. This cumulative yield is also reported as up to 54 short tons per acre ( 1 short ton $=2000 \mathrm{lb}$ ), which may account for some of the misleading figures quoted for bamboo productivity in the USA. The maximum productivity recorded for any natural ecosystem is $88 \mathrm{t} / \mathrm{ha} / \mathrm{year}$ (for floodplain grass in the Amazon; Piedade et al., 1991), which is close to the maximum figure reported for crops (about 88-91 t/ha/year for above-ground yield of fertilized sugar cane; Alexander et al., 1982; Giamalva et al., 1984). Both of these examples represent roughly the maximum possible plant productivity with the advantages of $\mathrm{C}_{4}$ photosynthesis and no nutrient limitations, and are equivalent to about 39-40 short tons (35-36 imperial or long tons) per acre per year.

The most productive bamboo stand reported by Sturkie et al. (1968) was probably fertilized; recommended applications, assumed to be annual, were N:P:K 80:35:50 lb/acre (91:40:57 kg/ha). Other Phyllostachys species achieved lower annual yields (2.0-5.8 t/ha/year, or 0.8-2.3 t/acre/year, including up to $21 \%$ in the form of branches). In trials at Camden, Alabama (1959-1966, plots $65 \mathrm{~m}$ x $65 \mathrm{~m}$, plants spaced $2.4 \mathrm{~m}$ x 2.4 $\mathrm{m})$, Phyllostachys bambusoides out-performed Pinus taeda (Loblolly pine) by a factor of nearly 2:1 in terms of above-ground dry matter production over the first 7 years of growth (stems and branches, barkfree in the case of $P$. taeda), producing $12.4 \mathrm{t} / \mathrm{acre}(1.8 \mathrm{t} / \mathrm{acre} / \mathrm{year}$ or $4.4 \mathrm{t} / \mathrm{ha} / \mathrm{year})$ compared with pine productivity of $7.1 \mathrm{t} / \mathrm{acre}(1.0 \mathrm{t} / \mathrm{acre} / \mathrm{year}$ or $2.5 \mathrm{t} / \mathrm{ha} / \mathrm{year})$.

Adamson et al. (1978) found that shoot production of various Phyllostachys species at Savannah, Georgia (latitude $32^{\circ} \mathrm{N}$ ), varied greatly between years in response to environmental factors. They estimated that sustained yields of over 4 short tons/acre/year $(9.1 \mathrm{t} / \mathrm{ha} /$ year $)$ were attainable for established stands of $P$. bambusoides. In trials with cutting this species on 5, 6 and 7-year cycles, yields were 3.9-4.4 short tons/acre/year (9.0-9.9 t/ha/year), although one 3-year cycle produced 5.9 short tons/acre/year (13.5 $\mathrm{t} /$ ha/year). Newly-established stands responded positively to $\mathrm{N}$ fertilizer, especially when applied in early spring.

\section{Potential for New Applications in the Americas}

Assuming that markets can be identified and established for domestically-grown bamboo products (e.g. fresh or canned bamboo shoots, bamboo poles, bamboo flooring) there may be some commercial potential for certain bamboo species (notably Phyllostachys spp.) in the warmer, wetter parts of the U.S. As indicated by previous USDA interest, the U.S. South-East is a likely candidate region, although the prevalence of frost in the southern Appalachian mountains may set a northern limit to the commercial growing of bamboo. Widespread growing for bioenergy production is unlikely, though, both for reasons of climate limitation and 
because bamboo productivity is no greater than, and in many cases less than, other candidate bioenergy crops.

Based upon the figures available from overseas, as well as the limited trials conducted in the U.S., intensively managed bamboo stands with fertilization may be capable of producing over $10 \mathrm{t} / \mathrm{ha} / \mathrm{year}$ ( 4 metric tonnes per acre per year), but a combination of variable soils and uneven management could significantly reduce this figure over large plantation areas. Nevertheless, bamboo appears to share a number of desirable fuel characteristics with other bioenergy feedstocks, including a low moisture content at the time of harvest (Table 2). The waste products from bamboo processing for other purposes may also be suitable for energy recovery using established biomass feedstock handling equipment.

Elsewhere in the Americas, notably Central America, there has been interest expressed in building upon local agricultural experience with management of bamboo stands, in order to provide fuel for conventional steamgeneration power plants (Alger, Fielden, Wagner, pers. comms.). Under these conditions, the local skills base may prove more significant in determining project success than the potential productivity of the bioenergy feedstock.

\section{Conclusions}

Bamboo may indeed have potential as a bioenergy or fiber crop for niche markets, but little experience has been gained outside Asia since the 1960s in selecting well-adapted species/ genotypes, or in estimating the productivity of the crop under U.S. conditions. Reports of high productivity appear to emanate from smallscale trials in the 1950s-1960s in Alabama, but there is little evidence overall that bamboo is significantly more productive than other candidate bioenergy crops. Bamboo has good fiber quality for paper-making, and it shares a number of desirable fuel characteristics with certain other bioenergy feedstocks, such as low ash content and alkali index. Its heating value is lower than many woody biomass feedstocks but higher than most agricultural residues, grasses and straws. In common with certain other potential energy crops, nonfuel applications of bamboo biomass may be actually more profitable than energy recovery, although these other applications might be used as a means of supplementing the income of bamboo bioenergy growers. Alternatively, bioenergy might provide a market for utilization of waste materials from thinning/harvesting of bamboo stands grown for other purposes. Drawbacks include the near-impossibility of selective breeding, given the poor state of knowledge on bamboo reproduction.

Further research is clearly required on propagation techniques to increase multiplication rates, although recent studies in India appear promising. Large-scale trials are needed in order to develop recommendations for cost-effective establishment and stand management, and mechanized harvesting needs to be developed

for countries with high labor costs. The economics of bamboo production require thorough evaluation, both for single-use and multiple-product scenarios.

\section{Contacts for Further Information}

International Network for Bamboo and Rattan (INBAR)

c/o International Development Research Center (IDRC), Canada

Publications Department

17 Jorbagh

New Delhi 110003 


\section{INDIA}

Fax: +91 (11) 462-2707

http://www.idrc.ca/media/inbar_bamboo_e.html

American Bamboo Society (useful Web site with lots of information and further contacts)

c/o Michael Bartholomew

750 Krumkill Road

Albany, NY 12203-5976

USA

http://www.bamboo.org/abs/index.shtml

Gil Lovell, Curator of Agronomy

USDA Plant Genetic Resources Conservation Unit

College of Agricultural and Environmental Sciences

University of Georgia Griffin Campus

Georgia Experimental Station

1109 Experiment Street

Griffin, GA 30223-1797

USA

Tel. +1 (770) 228-7255

Email: glovell@gaes.griffin.peachnet.edu

John Woods

West Wind Technology

5 South Hill Street

Athens, TN 37303

USA

Tel. +1 (423) 745-5087

Fax +1 (423) 744-8689

Email: jewwwt@usit.net

http://esi.athenstn.com/wwt/wwt.html

John Alger

Buckdancer Consultants

59 Summer Haven Road

Swannanoa, NC 28778

USA

Tel. +1 (828) 299-0799

Fax +1 (828) 298-0521

Email: alger@cheta.net

Bamboo flooring and "environmentally friendly" bamboo building materials:

Plyboo America, Inc.

745 Chestnut Ridge Road

Kirkville, NY 13082

USA

Tel. +1 (315) 687 - 3240

Fax: +1 (315) $687-5177$

Email: plyboo@aol.com 
http://www.plyboo-america.com

Book: Plantation bamboo (see FURTHER READING below)

Dr. P. Shanmughavel

Dept. of Botany

Bharathiar University

Coimbatore 641046

Tamil Nadu

INDIA

Fax: +91 (422) 422387

Email: botany@as250.bharathi.ernet.in

\section{References}

Adamson, W.C., G.A. White, H.T. Derigo and W.O. Hawley (1978) Bamboo Production Research at Savannah, Georgia, 1956-77. USDA-ARS-S-176. U.S. Department of Agriculture, Agricultural Research Service, Savannah, Georgia. 17 pp.

Alexander, A.G., W. Allison, C. Gonzalez-Molina, J. Ortiz-Velez, G. Ramirez, J. Velez-Santiago, A. Velez and T.L.Chu (1982) Production of sugarcase and tropical grasses and as renewable energy source. Final Report (01-Jun-77 to 31-May-82) to U.S. Department of Energy. Center for Energy and Environment Research, University of Puerto Rico, Rio Pedras.

Bagby, M.O., G.H. Nelson, E.G. Helman and T.F. Clark (1971) Determination of lignin in non-wood plant fiber sources. Tappi 54, 1876-1878.

Baxter, L.L., T.R. Miles, T.R. Miles, Jr., B.M. Jenkins, T. Milne, D. Dayton, R.W. Bryers and L.L. Oden (1998) The behavior of inorganic materials in biomass-fired power boilers: field and laboratory experiences. Fuel Processing Technology 54, 47-78.

Chao, C.S. (1989) A Guide to Bamboos Grown in Britain. Royal Botanic Gardens, Kew, U.K. 47 pp.

Dayton, D.C. and T.A. Milne (1996) Laboratory measurements of alkali metal containing vapors released during biomass combustion. In: Application of Advanced Technologies to Ash-Related Problems in Boilers (eds. L. Baxter and R. DeSollar). Plenum Press: New York. pp. 161-185.

Dence, C.W. (1992) The determination of lignin. In: Methods in Lignin Chemistry (eds. S.Y. Lin and C.W. Dence). Springer-Verlag, Berlin - New York. pp. 35-57.

Environmental Building News (1999) Bamboo flooring. Citation from Environmental Building News, West River Communications, Brattleboro, Vermont, USA, Vol. 6 (10), November 1997. Forest Products Journal 49 (1), 6.

El Bassam, N. (1998) Energy Plant Species: their use and impact on environment and development. James and James, London. $321 \mathrm{pp}$. 
Fengel, D and Wegener, G. (1984) Wood: Chemistry, Ultrastucture, Reactions. Walter de Gruyter Publishers, Berlin - New York. pp. 56-59.

Giamalva, M.J., S.J. Clarke and J.M. Stein (1984) Sugarcane hybrids for biomass. Biomass 6, 61-68.

Higuchi, H. (1957) Biochemical studies of lignin formation, III. Physiologia Plantarum 10, 633-648.

IFAR/INBAR (1991) Research Needs for Bamboo and Rattan to the Year 2000. Tropical Tree Crops Program, International Fund for Agricultural Research/ International Network for Bamboo and Rattan, Singapore.

Isagi, Y., T. Kawahara and K. Kamo (1993) Biomass and net production in a bamboo Phyllostachys bambusoides stand. Ecological Research 8, 123-133.

Isagi, Y., T. Kawahara, K. Kamo and H. Ito (1997) Net production and carbon cycling in a bamboo Phyllostachys pubescens stand. Plant Ecology 130, 41-52.

Jones, C.A. (1985) $C_{4}$ Grasses and Cereals: Growth, Development and Stress Response. John Wiley, New York. 419 pp.

Lipangile, T.N. (1987) Bamboo and wooden water pipes. Ambio 16, 299-301.

McLaughlin, S.B., R. Samson, D. Bransby and A. Wiselogel (1996) Evaluating physical, chemical and energetic properties of perennial grasses as biofuels. In: Bioenergy '96, Proc. $7^{\text {th }}$ National Bioenergy Conference, Nashville, Sept. 1996. pp. 1-8.

Miles, T.R., T.R. Miles, Jr., L.L. Baxter, R.W. Bryers, B.M. Jenkins and L.L. Oden (1996) Boiler deposits from firing biomass fuels. Biomass and Bioenergy 10, 125-138.

Molini, A.E. and J.G. Irizarry (1983) Bamboo as a renewable energy resource. In: Proceedings of the First Pan American Congress on Energy and Second National Conference on Renewable Energy Technologies, 1-7 August, 1982, San Juan, Puerto Rico. Report No. CONF-8308231, Center for Energy and Environment Research, San Juan.

Nadgauda, R.S., C.K. John, M.S. Joshi, V.A. Parasharami, and A.F. Mascarenhas (1997) Application of in vitro techniques for bamboo improvement. In: The Bamboos: Proceedings of an International Symposium, London, 25-29 March 1996. (Chapman, G.P., ed.). Linnean Society Symposium Series No. 19, Academic Press for the Linnean Society of London, San Diego. pp.163-177.

Nordin, A. (1994) Chemical elemental characteristics of biomass fuels. Biomass and Bioenergy 6, 339347.

Panshin, A.J. and C. de Zeeuw (1980) Textbook on Wood Technology: Structure, Identification, Properties, and Uses of the Commercial Woods of the United States and Canada. McGraw-Hill, New York. pp. 268-269.

Phillips, M. (1939) Journal of the Association of Official Agricultural Chemists 22, 422. 
Piatti, L. (1947) Flüssige brennstoff aus bambus (liquid fuel from bamboo). Schweizer Archiv für Angewandte Wissenschaft und Technik 13, 370-376.

Piedade, M.T.F., W.J. Junk and S.P. Long (1991) The productivity of the $\mathrm{C}_{4}$ grass Echinochloa polystachya on the Amazon floodplain. Ecology 72, 1456-1463.

Qiu, G.X., Y.K. Shen, D.Y. Li, Z.W. Wang, Q.M. Huang, D.D. Yang and A.X. Gao (1992) Bamboo in sub-tropical eastern China. In: Primary Productivity of Grass Ecosystems of the Tropics and Subtropics (S.P. Long et al., eds.). Chapman and Hall, London. pp. 159-188.

Ram, M,S, and G. Seenayya (1991) Production of ethanol from straw and bamboo pulp by primary isolates of Clostridium thermocellum. World Journal of Microbiology and Biotechnology 7, 372378.

Scurlock, J.M.O. (1999) Miscanthus: a review of European experience with a novel energy crop. ORNL Technical Memorandum TM-13732, Oak Ridge National Laboratory, Oak Ridge, Tennessee. 18 pp.

Shanmughavel, P. and K. Francis (1996) Above ground biomass production and nutrient distribution in growing bamboo (Bambusa bambos (L.) Voss). Biomass and Bioenergy 10, 383-391.

Sturkie, D.G., V.L. Brown and W.J. Watson (1968) Bamboo Growing in Alabama. Bulletin No. 387, USDA Agricultural Experiment Station, Auburn University, Alabama. 30 pp.

Suwannapinunt, W. (1983) A study on the biomass of Thyrsostachys siamensis (Gamble) forest at HinLap, Kanchanaburi. Journal of Bamboo Research 2, 227-237.

Taylor, A.H. and Z.S. Qin (1987) Culm dynamics and dry matter production of bamboos in Wolong and Tanajiahe Giant Panda Reserves, Sichuan, China. Journal of Applied Ecology 24, 419-433.

Tewari, D.N. (1992) A Monograph on Bamboo. International Book Distributors, Dehra Dun, India. 498 pp.

Tripathi S.K. and K.P. Singh (1994) Productivity and nutrient cycling in recently harvested and mature bamboo savannas in the dry tropics. Journal of Applied Ecology 31, 109-124.

Veblen, T.T., Schlegel and B. Escobar (1980) Dry matter production of two species of bamboo (Chusquea culeou and C. tenuiflora) in south-central Chile. Journal of Ecology 68, 397-404.

Woods, J.E. (1996) Bamboo: Agribusiness Opportunities. Proposals presented to ORNL Bioenergy Feedstock Development Program by West Wind Technology, Inc., Athens, Tennessee.

\section{Further Reading}

Azmy Mohamed, Norini Haron, and Wan Razali Wan Mohamed (1997) Management Guidelines and Economics of Natural Bamboo Stands. FRIM Technical Information Handbook No. 15, Forest Research Institute of Malaysia, Kuala Lumpur. 40 pp. 
Farrelly, D. (1984) The Book of Bamboo. Sierra Club Books, San Francisco. 332 pp. [Comprehensive illustrated review for the non-scientist, with instructions for cultivation and examples of utilization].

Ohrnberger, D. (1999) The Bamboos of the World: annotated nomenclature and literature of the species and the higher and lower taxa. ISBN 0444500200 Elsevier, Amsterdam and New York. 585 pp.

Recht, C. and M.F. Wetterwald (1992) Bamboos. Translated from the German by M. Walters. Timber Press, Portland, Oregon. 128 pp. [Good elementary guide with clear illustrations and diagrams.]

Shanmughavel, P. (1998) Plantation Bamboo. [Covers all aspects of bamboo, including productivity. Available directly from the author (see CONTACTS above), price U.S. \$60.] 

ORNL/TM-199/264

\section{INTERNAL DISTRIBUTION}

$\begin{aligned} \text { 1-62. } & \text { J. H. Cushman } \\ 63 . & \text { D. E. Fowler } \\ 64 . & \text { S. G. Hildebrand } \\ 65 . & \text { G. K. Jacobs } \\ 66 . & \text { P. Kanciruk } \\ \text { 67. } & \text { J. M. Loar } \\ 68 . & \text { T. E. Myrick }\end{aligned}$
69. D. E. Reichle
70-71. J. M .O. Scurlock
72. Central Research Library
73-75. ESD Library
76-77. Laboratory Records-OSTI
78. Laboratory Records-RC

\section{EXTERNAL DISTRIBUTION}

79. David Bransby, Dept. of Agronomy and Soils, 202 Funchess Hall, Auburn University, AL 36849

80. John Alger, Buckdancer Consultants, 59 Summer Haven Road, Swannanoa, NC 28778

81. Michael Bartholomew, American Bamboo Society, 750 Krumkill Road, Albany, NY 122035976

82. E. G. Cumesty, Assistant Manager for Laboratories and Site Manager, Department of Energy, Oak Ridge National Laboratory, P.O. Box 2008, Oak Ridge, TN 37831-6269

83. Jerry Elwood, Acting Director, Environmental Sciences Division, ER-74, Department of Energy, 19901 Germantown Road, Germantown, MD 20874

84. Peter Edwards, Geobotanical Institute, Swiss Federal Institute of Technology, Zürichbergstrasse 38, CH-8044 Zürich, Switzerland

85. Derrick Fielden, CDC Investments Group, Commonwealth Development Corporation, One Bessborough Gardens, London SW1V 2JO, U.K.

86. J. P. Giesy, College of Natural Science, Department of Zoology, Michigan State University, 203 Natural Science Building, East Lansing, MI 48824-1115

87. International Network for Bamboo and Rattan, Publications Department, 17 Jorbagh, New Delhi 110003, INDIA

88. Gil Lovell, Curator of Agronomy, USDA Plant Genetic Resources Conservation Unit, College of Agricultural and Environmental Sciences, University of Georgia Griffin Campus, Georgia Experimental Station, 1109 Experiment Street, Griffin, GA 30223-1797

89. A. A. Lucier, National Council of the Paper Industry For Air and Stream Improvement, Inc., P.O. Box 13318, Research Triangle Park, NC 27709-3318 
90. Michael C. MacCracken, Director, Office of the U.S. Global Change Research Program, Code YS-1, 300 E Street, SW, Washington, DC 20546

91. Plyboo America, Inc., 745 Chestnut Ridge Road, Kirkville, NY 13082

92. Dr. Huang Qi-min, Subtropical Forestry Research Institute, Academica Sinica, Fuyang, Zhejiang 311400, CHINA

93. L. Robinson, Director, Environmental Sciences Institute, Florida A\&M University, Science Research Facility, 1520 S. Bronough Street, Tallahassee, FL 32307

94. Dr. P. Shanmughavel, Dept. of Botany, Bharathiar University, Coimbatore 641046, Tamil Nadu, INDIA

95. J. M. Tiedje, University Distinguished Professor and Director, Center for Microbial Ecology, Michigan State University, 540 Plant and Soil Sciences Building, East Lansing, MI 48824

96. Vince Wagner, International Bamboo Development Company, 1000 East 11th St., Kansas City, MO 64106

97. Forbes Walker, Dept. of Plant and Soil Science, University of Tennessee, P.O. Box 1071, Knoxville, TN 37901-1071

98. Dr. Jeremy Woods, Division of Life Sciences, Franklin-Wilkins Bldg, King's College London, 150 Stamford Street, London SE1 8WA, U.K.

99. John Woods, West Wind Technology, 5 South Hill Street, Athens, TN 37303

100. Prof. Shen Yun-gang, Shanghai Institute of Plant Physiology, Academia Sinica, 300 Fenglin Road, Shanghai 200032, CHINA 